\title{
Internet adoption in the newsroom: Journalists' use of the Internet explained by attitudes and perceived functions
}

\author{
LIESBETH HERMANS, MAURICE VERGEER \\ and ALEXANDER PLEIJTER
}

\section{Abstract}

Journalists differ in the degree to which they have adopted the Internet professionally. While earlier studies were predominantly descriptive, this study explains why journalists differ in the amount (time spent on the Internet) and nature (diversity of Internet applications) of their use of the Internet. Based on a random sample of members of the Dutch Association of Journalists, results indicate that the digital divide in terms of demographic characteristics is absent. The perceived functionality of the Internet as a professional tool is the most important explanatory factor for the use of the Internet. Surprisingly, professional attitudes towards journalistic quality are not reflected in journalists' use of the Internet.

Keywords: Internet use, Internet adoption, newsroom, journalism

\section{Introduction}

New technological innovations play an important part in journalism: this is no longer a moot point today. Publications dealing with recent changes in journalism more or less accept the major impact of the Internet in this process. This in turn is leading to a rethink and a redefinition of traditional journalism (Bivens, 2008; Deuze, 2005; Singer, 2003). The Internet is affecting many aspects of the news production process. The Internet is thought to have had beneficial effects, it is more efficient, faster and cost-effective (Lasica, 2003; Pavlik, 2001), or to have had detrimental effects on quality because Internet information can be unreliable and may threaten traditional journalistic values such as credibility and objectivity (Hall, 2001; Manning, 2001; Ruggiero, 2004). However, in practice, the great influence the Internet has on the daily work of journalists is commonly accepted. After some initial hesitation of news organizations in the early 1990s to implement the new technology (Ngu- 
yen, 2008), journalists nowadays increasingly adopt the Internet as a useful tool for information gathering and producing.

Previous studies on journalists' use of the Internet concluded that over the last few years this has increased globally. Mostly studies of a descriptive nature, they show an increase in Internet use, and list functions and applications offered by the Internet to aid journalistic activities (cf. Garrison, 2000, 2003; Ketterer, 2003; Middleberg and Ross, 2001; Lünenbürger-Reidenbach, Petersen and Wagensonner, 2000; Quinn, 1999; Rhee and Kim, 2004).

Since 2002 there is almost total acceptance of the Internet as a journalistic tool, it is important to advance by gaining a better understanding of how and why journalists use the Internet. In this study we provide increased insight into the use of the Internet in the daily practice of journalists by using an explanatory model to test assumptions about journalists' use of the Internet found in previous research. Our research thus provides further explanations for the often discussed relationship between journalists and the Internet.

\section{The adoption of the Internet}

Previous studies on the adoption of the Internet show that there are differences between journalists in the way they use the Internet in their work. How these differences between individual journalists can be explained is as yet unknown. We will analyze more closely explanations for these differences, using basic assumptions found in several theoretical approaches to devise hypotheses.

This study complements past research on two accounts. Firstly, by examining Internet adoption by means of two specific aspects of adoption: (a) the amount of time spent by journalists on the Internet and, (b) the diversity of Internet applications used by journalists. The amount of time spent on the Internet reflects the degree to which the Internet influences daily work practices, while the diversity of use reflects the way new applications on the Internet have already been implemented into journalistic practice.

Secondly, previous studies have paid little attention to finding out why some journalists use the Internet frequently and use many different Internet applications while others do not. These considerations led us to formulate the following research question:

To what degree can the level and the nature of Internet use by journalists be explained by demographic characteristics, socialization, perceived functionality of the Internet, perceived credibility of Internet 
information, and perceived impact of the Internet on journalistic quality?

\section{Hypotheses}

In this section, hypotheses derived from theoretical notions and previous research are presented. Based on previous research identifying associations between the use of the Internet and demographics (Atkin, Jeffres and Neuendorf, 1998; Nie and Erbring, 2000; Flanagin and Metzger, 2000), the hypotheses concerning demographics were as follows:

1. The younger journalists are, the more time they spend on the Internet;

2. The more highly educated journalists are, the more time they spend on the Internet;

3. The younger journalists are, the greater the diversity of Internet applications they use;

4. The more highly educated journalists are, the greater the diversity of Internet applications they use.

Based on previous research identifying the influence of socialization (Berkowitz, 1992; Gans, 1980), the following hypotheses were formulated:

5. Journalists that were exposed more to professional socialization, spend less time on the Internet;

6. Journalists that were exposed more to professional socialization, use a smaller diversity of Internet applications;

7. The more Internet experience journalists have, the more time they spend on the Internet;

8. The more Internet experience journalists have, the greater the diversity of Internet applications they use.

Several studies indicate the specific positions journalists occupy are related to their use of the Internet (Garrison 2003; Hermans, 2004; Paulussen 2004; Weaver, Beam, Brownlee, Voakes and Wilhoit, 2007). The hypotheses are formulated as follows:

9. Reporters spend less time on the Internet than editors and managers;

10. Reporters use a smaller range of Internet applications than editors and managers.

Based on previous research on journalists' perceptions of the Internet's usefulness (Garrison, 2000, 2003), we formulated the following hypotheses: 
11. The greater the degree of functionality attributed to the Internet by journalists, the more time they spend on the Internet;

12. The greater the degree of functionality attributed to the Internet by journalists, the larger the diversity of Internet applications they use.

Regarding the journalists' perception of the degree of Internet Information credibility (Chan, Lee and Pan, 2006; Garrison, 2000; Ruggiero, 2004), we formulated the following hypotheses:

13. The more journalists perceive online information as credible, the more time they spend on the Internet;

14. The perceived credibility of Internet information is correlated (i.e. positive or negative) with the diversity of Internet applications used.

Hypotheses on whether the idea that the advent of the Internet has affected the quality of journalism is reflected in the use of the Internet are derived from studies by Garrison (2000) and Pleijter, Hermans and Tebbe (2005):

15. The more journalists' view that the Internet has a negative impact on journalistic quality, the less time they spend on the Internet;

16. The more journalists' view that the Internet has a negative impact on journalistic quality, the smaller the range of Internet applications they use.

\section{Data}

The research and data collection are part of an ongoing longitudinal project concerning the relationship between the Internet and journalism practices in the Netherlands.

The target population consisted of journalists working in the Netherlands. The sampling frame was the membership database of the Dutch Association of Journalists (NVJ), representing an estimated $60 \%$ to $70 \%$ of all journalists in the Netherlands (Deuze, 2002: 49). The random sample was stratified in line with sections within the NVJ organization. Sections that did not include journalists, such as those involving student members and PR officials, were excluded in advance. In November 2001, we sent out by post 2000 questionnaires containing stamped self-addressed envelopes. In January 2002, we sent out reminders. Eventually, 685 questionnaires were returned, amounting to a response rate of $34.3 \%$. This response rate is considerably higher than that in similar 
foreign studies among journalists (Middleburg and Ross, 2001; Lünenbürger-Reidenbach, Petersen and Wagensonner, 2000).

Listwise deletion applied in analyses resulted in samples of 514 (time spent on the Internet) and 516 (diversity in use of Internet applications).

\section{Operationalization}

\section{Dependent variables}

Time spent on the Internet and e-mail at work is defined as the amount of time journalists actually use the Internet and e-mail. The time spent was measured using five categories: never or rarely, less than 1 hour, 1 hour to 2 hours, 2 to 4 hours, and 4 hours or more per day. To obtain a scale of ratio measurement level, the original scores were replaced with the categories' midpoints (i.e. $0, .5,1.5,3$, and 6).

Diversity in use of Internet applications was measured by asking journalists whether or not they used Internet applications in their occupational work (private use was excluded). These included the following applications: e-mail (used by $99 \%$ in our sample), Web surfing (95\%), search engines $(94 \%)$, newsletters and e-zines $(43 \%)$, press clipping services $(17 \%)$, news groups $(16 \%)$, chatting $(3 \%)$, and instant messaging $(5 \%)$. Diversity of Internet use was then determined by counting the number of different Internet applications used (ranging from 0 to 8 ).

\section{Independent variables}

Attitudes towards the Internet and journalism were measured using 5-point Likert-type scales. The Kaiser-Meyer-Olkin measure $(>.80)$ indicated that the data were suitable for factor analysis. This resulted, using commonly applied criteria (eigen value $>1$, factor loading $>.40$, factor loading other factors $<.20$, communality $>.20$ ) in seven clearly interpretable factors (see Appendix). The distinguished factors were the following ones.

Perceived functionality of the Internet was broken down into (a) the degree to which the Internet was perceived as being useful for information retrieval and verification (factor 1 , Cronbach's alpha $=.84$ ), (b) the degree to which Internet use was perceived as producing efficiency gains (factor 4, Cronbach's alpha $=.75$ ), and (c) the degree to which the Internet was used for interpersonal communication with the audience and with sources (factor 7, Cronbach's alpha $=.64$ ).

The degree of credibility of information on the Internet was broken down into three dimensions: (a) the degree to which information on the Internet was considered credible in general (factor 5, Cronbach's 
alpha $=.67)$, and $(\mathrm{b}$ and $\mathrm{c})$ the degree to which information from public organizations and information from private organizations on the Internet was considered credible (factors 6 and 2, Cronbach's alpha $=.79$ and .78 , respectively).

The degree to which the Internet was considered beneficial for journalistic quality constituted one factor (factor 3, Cronbach's alpha $=.75$ ).

After recoding negatively formulated statements, sum scores were calculated, with higher scores on the variable indicating greater endorsement of the label of the dimension.

Journalistic socialization was measured on two dimensions: "professional socialization" and "Internet experience". Professional socialization was measured using two indicators: (a) whether or not journalists participated in vocational training (i.e. school of journalism); (b) the number of years journalists had work experience in journalism. The degree to which journalists had gained Internet experience was also measured using two indicators: (c) whether journalists participated in a course on how to use the Internet; and (d) the number of years they had been using the Internet in journalism and the number of years they had been using e-mail. Because the latter measurements (i. e. years of Internet and years of e-mail use) correlated strongly $(\mathrm{r}=.71)$, sum scores were calculated.

The demographic characteristics of journalists were measured by age and education. Age was determined by asking respondents for their date of birth. Highest educational attainment level consisted of three categories: "university", "higher professional training", and "other".

The positions journalists can occupy, indicated by job titles in journalism, are hardly uniform. Activities ascribed to these titles depend on the specific organization (Weaver, Beam, Brownlee, Voakes, and Wilhoit, 2007: 65-66). Therefore, position was measured by asking journalists what main task they perform. The general tasks that were distinguished were reporting, editing, and managing. For descriptive measures of the variables, see appendix $C$.

\section{Methods}

To test the hypotheses, we used hierarchical multiple regression analysis (Berry and Feldman 1985). In the first step (model 1), we added demographic characteristics such as age, vocational training, position, experience as a journalist, and Internet experience. In the second step (model 2), we added perceived functionality and credibility, and opinions on the consequences for journalistic quality. This procedure allows for identifying possible indirect effects of background characteristics (i.e. demographics, socialization and position) mediated by attitudes (i. e. perceived 
functionality, credibility and quality gain). Prior to the analyses, we checked whether the conventional assumptions of level of measurement, linearity, and homoscedasticity were not violated (Berry, 1993). Because of the nominal level of measurement of several independent variables (highest educational attainment level and position), the categories of these variables were entered into the regression analysis as dummy variables (Hardy, 1993). The reference category was coded as zero, while the remaining categories were coded as one. To assess the relative importance of these nominal variables, we calculated compound variables on the basis of un-standardized regression coefficients (Eisinga, Scheepers and Van Snippenburg, 1991).

\section{Results}

Table 1 presents the hierarchical multiple regression analysis for time spent on the Internet. This table shows that the demographic characteristics of age and education were unrelated to time spent on the Internet, rejecting hypotheses 1 and 2 . This implies that a structural digital divide is absent for journalists.

The number of years of work experience and whether journalists have had vocational training (both indicative for professional socialization) were both not related to time spent on the Internet. Therefore, hypothesis 5 was consistently rejected.

Whether a journalist has received a course on using the Internet is unrelated to their time spent on the Internet. However, the more years journalists have had of Internet experience, the more time they spent on the Internet $(\beta=.195)$. Thus, these findings show partial support for hypothesis 7 .

The positions of journalists within their organizations also correlated with time spent on the Internet: both managers $(\beta=.181)$ and editors $(\beta=.167)$ spent more time on the Internet than reporters, as was predicted in hypothesis 9 .

In addition to these explanations, we also looked at attitudes towards functionality and credibility and opinions on journalism in model $1 \mathrm{~b}$. This shows that the perceived functionality of Internet information was important in explaining time spent on the Internet. The more journalists felt that using the Internet was more efficient, the more time they spent on it $(\beta=.109)$. The main explanatory factor for time spent on the Internet, however, proved to be information retrieval and verification $(\beta=.341)$. The ease with which the Internet allowed journalists to communicate with sources and the audience also influenced time spent on the Internet $(\beta=.134)$. Hypothesis 11 , therefore, was not rejected. 
Table 1. Hierarchical regression analysis of time spent on the Internet on opinions of the Internet and journalistic quality.

\begin{tabular}{|c|c|c|}
\hline & Model 1a & Model $1 \mathrm{~b}$ \\
\hline \multicolumn{3}{|l|}{ Demographics } \\
\hline Age & 0.001 & 0.051 \\
\hline Education (compound coefficient) & 0.064 & 0.058 \\
\hline Higher professional training (coded as 0 ) & ref & ref \\
\hline University and higher (coded as 1 ) & $(0.056)$ & $(0.061)$ \\
\hline Other (coded as 1$)$ & $(-0.018)$ & $(0.012)$ \\
\hline \multicolumn{3}{|l|}{ Socialization } \\
\hline \multicolumn{3}{|l|}{ Professional socialization } \\
\hline Vocational training & 0.035 & 0.021 \\
\hline Years of work experience & -0.100 & -0.066 \\
\hline \multicolumn{3}{|l|}{ Internet experience } \\
\hline Courses in Internet use for journalists & 0.028 & 0.054 \\
\hline Experience using the Internet and e-mail & 0.195 & 0.089 \\
\hline \multicolumn{3}{|l|}{ Position } \\
\hline Position (compound coefficient) & 0.209 & 0.153 \\
\hline Reporters (coded as 0$)$ & ref & ref \\
\hline Managers (coded as 1$)$ & $(0.181)$ & $(\mathbf{0 . 1 3 4})$ \\
\hline Editors (coded as 1) & $(0.167)$ & $(0.123)$ \\
\hline \multicolumn{3}{|l|}{ Perceived functionality } \\
\hline Efficiency & & 0.109 \\
\hline Information retrieval and verification & & 0.341 \\
\hline Interpersonal communication with audience and sources & & 0.134 \\
\hline \multicolumn{3}{|l|}{ Credibility } \\
\hline Internet related trust/credibility & & -0.042 \\
\hline Web info public organizations & & -0.064 \\
\hline Web info private organizations & & 0.020 \\
\hline \multicolumn{3}{|l|}{ Quality } \\
\hline \multirow[t]{3}{*}{ Quality improvement due to the Internet } & & -0.080 \\
\hline & 0.096 & 0.278 \\
\hline & & 0.182 \\
\hline
\end{tabular}

$n=514$ (after listwise deletion). Coefficients have been standardized. Coefficients in brackets are coefficients of the dummy variables. Coefficients printed in bold are significant at $p<.05$, one-sided. $r e f=$ reference category.

The degree to which journalists perceive information on the Internet as credible, both in general and taking into account the type of source (i. e. public or private organizations), proved to have no effect on time spent on the Internet. Hypothesis 13, therefore, was rejected.

With regard to journalistic quality, it turned out that the more journalists felt journalistic quality benefited from the Internet, the less time they 
spent on the Internet $(\beta=.080)$. Though this effect was small, it was contrary to expectation as framed in hypothesis 15 .

In comparison with model $1 \mathrm{a}$, the effects of Internet experience ( $\beta=.089)$ and position in the organization $(\beta=.153)$ in model $1 \mathrm{~b}$ have decreased, but are still statistically significant. Because the effect of Internet experience was cut by more than half, we may conclude that the more Internet experience journalists had, the more time they spent on the Internet because they used it predominantly for functional purposes.

Table 2 presents the regression analysis for diversity in Internet use. This table shows that, concerning demographic characteristics, the older journalists were, the smaller the range of Internet applications they used $(\beta=-.201)$. Hypothesis 3, therefore, was not rejected. Education proved to be unrelated to diversity of Internet use. Therefore hypothesis 4 was rejected.

Looking at professional socialization, we can conclude that the number of years of work experience and vocational training are not related to diversity in Internet use. Hypothesis 6, therefore, was consistently rejected. Having received a course on the use of the Internet is unrelated to the diversity of Internet applications. However, the number of years of Internet experience had a significant positive effect on diversity in use of Internet applications $(\beta=.276)$ : the more years of experience journalists had with the Internet, the greater the diversity of applications they used. These findings only partially confirmed hypothesis 8 .

There proved to be no differences in diversity of Internet use between journalists in various positions within their organizations. Hypothesis 10 , therefore, was rejected.

In model $2 \mathrm{~b}$, we added attitudes and opinions on the Internet and journalism. The results showed that perceived functionality of Internet information was important in explaining the diversity in use of Internet applications. The more journalists find the Internet useful for information retrieval and verification, the greater number of different Internet applications they use $(\beta=.398)$. Also, the more journalists find that the Internet makes their job more efficient, is related to more diverse use of Internet applications $(\beta=.122)$. The degree to which journalists perceive the Internet as easy for communication with sources and the audience, is also related to a more divers use of Internet applications $(\beta=.151)$. These findings consistently confirm expectations formulated in Hypothesis 12 .

The degree to which journalists believe information on the Internet to be credible proved to have no relation to diversity in use of Internet applications. Earlier, we provided arguments for a positive relation (more credibility leads to more diverse use of applications) and argu- 
Table 2. Hierarchical regression analysis of diversity in Internet use on opinions of the Internet and journalistic quality.

\begin{tabular}{|c|c|c|}
\hline & Model 2a & Model 2b \\
\hline \multicolumn{3}{|l|}{ Demographics } \\
\hline Age & -0.201 & -0.130 \\
\hline Educational attainment level & 0.029 & 0.046 \\
\hline Higher professional training (coded as 0 ) & ref & ref \\
\hline University and higher (coded as 1) & $(-0.031)$ & $(-0.035)$ \\
\hline Other (coded as 1) & $(-0.013)$ & $(0.021)$ \\
\hline \multicolumn{3}{|l|}{ Socialization } \\
\hline \multicolumn{3}{|l|}{ Professional socialization } \\
\hline Vocational training & -0.058 & -0.075 \\
\hline Years of work experience & 0.003 & 0.029 \\
\hline \multicolumn{3}{|l|}{ Internet experience } \\
\hline Courses in Internet use for journalists & -0.046 & -0.016 \\
\hline Experience using the Internet and e-mail & 0.276 & 0.148 \\
\hline \multicolumn{3}{|l|}{ Position } \\
\hline Position (compound coefficient) & 0.065 & 0.004 \\
\hline Reporters (coded as 0 ) & ref & ref \\
\hline Managers (coded as 1$)$ & $(0.056)$ & $(0.005)$ \\
\hline Editors (coded as 1) & $(0.053)$ & $(0.003)$ \\
\hline \multicolumn{3}{|l|}{ Perceived functionality } \\
\hline Efficiency & & 0.122 \\
\hline Information retrieval and verification & & 0.398 \\
\hline Interpersonal communication with audience and sources & & 0.151 \\
\hline \multicolumn{3}{|l|}{ Credibility } \\
\hline Internet related trust/credibility & & -0.046 \\
\hline Web info public organizations & & -0.053 \\
\hline Web info private organizations & & -0.059 \\
\hline \multicolumn{3}{|l|}{ Quality } \\
\hline \multirow[t]{3}{*}{ Quality improvement due to the Internet } & & -0.056 \\
\hline & 0.111 & 0.362 \\
\hline & & 0.252 \\
\hline
\end{tabular}

$n=514$ (after listwise deletion). Coefficients have been standardized. Coefficients between brackets are coefficients of the dummy variables. Coefficients printed in bold are significant at $p<.05$, one-sided. $r e f=$ reference category.

ments for a negative relation (more credibility leads to less diverse use of applications). However, neither relation proved to exist. Therefore, hypothesis 14 was rejected.

The degree to which journalists felt that the Internet had a positive impact on the quality of journalism also proved to be unrelated to diversity in use of Internet applications. Hypothesis 16 was rejected. 
Adding journalists' attitudes to and opinions about the Internet in model $2 \mathrm{~b}$ proved to decrease the effects of age $(\beta=-.130)$ and Internet experience $(\beta=.148)$, though these remained statistically significant. This led us to conclude that the negative relation between age and diversity in Internet use could partly be interpreted as signifying that older journalists felt that the Internet was less functional. The relation between Internet experience and diversity in Internet use could also partially be interpreted in terms of experienced functionality: the more Internet experience journalists had, the greater the diversity of applications they used because journalists perceive the Internet to be more functional in their daily work. In model $2 \mathrm{~b}$, and in contrast with model $2 \mathrm{a}$, having vocation training proved to be significantly related to the diversity of Internet applications used: journalists who had completed vocational training used the Internet in less diverse ways than journalists who had not completed such a program $(\beta=-.075)$. This finding does not confirm hypothesis 6 .

\section{Conclusions and discussion}

Several studies have shown that there are many differences in the way journalists use the Internet professionally. Our research aimed to explain differences in the way journalists apply the Internet, based on theoretically derived hypotheses. This takes us a step beyond the majority of descriptive studies that have appeared in this field and goes some way towards filling existing lacuna in this field (cf. Garrison, 2003). Furthermore, we went beyond the standard conceptualizing of adoption as a discrete concept. Instead, we used two distinct measurements for adoption: time spent on the Internet and diversity in Internet use.

Because most journalists, at the time of the data collection, had been able to use the Internet for no more than five years, the results can be interpreted as a reflection of the initial adoption phase. As such, it provides a baseline model for future research on Internet adoption by journalists in the Netherlands. Future surveys on journalists' Internet use may extend the model to determine long-term changes. Since the Internet is relatively new and still developing in unpredictable ways, new technological innovations such as Web 2.0 need to be included in future research.

The results of this study shows that work related aspects are the most important reasons for journalists to use the Internet. The main explanatory factor for the use of the Internet is the perceived functionality: journalists replace their 'old' information gathering tools for 'new' online tools, because these are faster, time saving and deliver more information. Because these work related factors are very important, further re- 
search should be extended to include factors such as working routines in the newsroom, journalists' assignments, occupational role perceptions and media specific contexts.

Experience of using the Internet is another important explanation for increased Internet adoption. Journalists with more Internet experience use it more and display more Internet aptitude (i. e. diversity of use). This seems logical, because with every new technology people need to learn new skills. Almost all journalists in 2002 used the Internet in some way and therefore have basic skills. Because it takes time to learn to use more complicated applications, journalists with more experience use them first. Looking at the diversity of applications used, the results show that journalists predominantly use three out of eight applications: e-mail, Web surfing and search engines. As such, the adoption process for these standard applications has been completed. The other applications (e.g. newsletters and e-zines, press clipping services, newsgroups, chat, Instant Message) show less penetration throughout the population of journalists. The lack of use of some of these applications may be explained by the fact that journalists do not find them beneficial to their journalistic practice (yet). As the Internet progresses and evolves, journalists cannot ignore the extended role the active audience will play in the news flow. Therefore, journalists need to adjust their news and information gathering tools and rethink their own task in the news production process. For instance, Trumbo, Sprecker, Dumlao, Yun and Duke (2001) found that more experience not only leads to more Internet use, but it also leads to a more critical way of dealing with online information. They call this "the voice of experience" (2001: 371). In our study there is no evidence for that: although there is a similar positive relation between experience and Internet use, there is also a negative relation between perceived journalistic quality gain because of the Internet and the use of the Internet. One interpretation for this finding is that journalists who have faith in the Internet as a journalistic tool may be easily satisfied with their search results on the Internet, while journalists who are more critical towards the Internet may cross-check every bit of information, which of course takes up much more time.

That functionality is the main consideration for journalists to use the Internet while journalism standards are of minor or no importance, is of great concern. To explain the interplay between the Internet and journalism, it is important to focus more in-depth on specific work related (i.e. specific tasks) and media related developments (i. e. print, web, and audio-visual) that will lead to further changes in journalism. Recent developments, such as distributing news for free (Internet newspapers and free dailies), and at the same time the increasing need for profit maximization to satisfy increasingly influential capital investors have their re- 
percussions on the work of journalists. In the Netherlands, this is best observed in the merger of a large number of regional newspaper titles into a few larger ones, and the subsequent downsizing of editorial boards. The reduction in staff numbers is thought to have resulted in a decline in the quality of the coverage of regional news. Editorial boards of Internet news sites have also merged (Dutch Media Authority, 2003). In this Dutch context, which may not differ from many other Western countries, cost effectiveness may well become the dominant business strategy for news production, if it is not already dominant today. Information and communication technology will be an important driver in rationalizing this news production process. The absence of a relation between performance considerations (i.e. credibility and quality) and the use of the Internet in our study raises questions as to the contribution of ICTs to journalism. Whether the practical advantages of the Internet outweigh the quality concerns relating, for example, to unreliable Internet information and sources (cf. Deuze, 2002) is difficult to assess at this point in time. However, the Internet will increase its role in the news production process. As such, journalism in the age of the Internet, having the function of social control, criticism and interpreter of news (cf. Weaver, Beam, Brownlee, Voakes and Wilhoit, 2007), is worthwhile careful and continuous monitoring.

\section{References}

Atkin, D. J., Jeffres, L. W. and Neuendorf, K. A. (1998). Understanding Internet adoption as telecommunication behavior. Journal of Broadcasting and Electronic Media, 42, 475-490.

Berkowitz, D. (1992). Routine news work and the what-a-story: A case study of organizational adaptation. Journal of Broadcasting and Electronic Media, 36, 45-60.

Berry, W. and Feldman, S. (1985). Multiple regression in practice. Newbury Park: Sage.

Berry, W. D. (1993). Understanding regression assumptions. Newbury Park: Sage.

Bivens, R. K. (2008). The Internet, mobile phones and blogging: How new media are transforming traditional journalism. Journalism Practice, 2, 113-129.

Chan, J. M., Lee, F. L. F. and Pan, Z. (2006). Online news meets established journalism: How China's journalists evaluate the credibility of news websites. New Media and Society, 8, 925-947.

Deuze, M. (2002). Journalists in the Netherlands: An analysis of the people, the issues and the (inter-) national environment. Amsterdam: Aksant.

Deuze, M. (2005). What is journalism? Professional identity and ideology of journalists reconsidered. Journalism, 6, 442-464.

Dutch Media Authority (2003). Mediaconcentratie in beeld. Concentratie en pluriformiteit van de Nederlandse media 2002 [Media concentration in view. Concentration and diversity of Dutch media 2002]. Hilversum: Dutch Media Authority.

Eisinga, R., Scheepers, P. and Van Snippenburg, L. (1991). The standardized effect of a compound of dummy variables or polynomial terms, Quality and Quantity, 25(4), $103-114$. 
Flanagin, A. J. and Metzger, M. J. (2000). Perceptions of Internet information credibility. Journalism and Mass Communication Quarterly, 77, 515-540.

Garrison, B. (2000). Journalists' perceptions of online information-gathering problems. Journalism and Mass Communication Quarterly, 77, 500-514.

Garrison, B. (2003). How newspaper reporters use the Web to gather news. Newspaper Research Journal, 24(3), 62-75.

Gans, H. J. (1980). Deciding what's news. New York Vintage Books.

Hall, J. (2001). Online journalism: A critical primer. London: Pluto.

Hardy, M. A. (1993). Regression analysis with dummy variables. London: Sage.

Hermans, L. (2004). Occupational practices of Dutch journalists in a television newsroom. In K. Renckstorf, D. McQuail, J. Rosenbaum and G. Schaap (Eds.), Action theory and communication research (pp. 355-370). Berlin: Mouton de Gruyter.

Ketterer, S. (2003). Oklahoma small dailies, weeklies use internet as reporting tool. Newspaper Research Journal, 24(2), 107-113.

Lasica, J. D. (2003). Blogs and journalism need each other. Nieman Reports, 57, $70-74$.

Lünenbürger-Reidenbach, W., Petersen J. and Wagensonner, T. (2000). Media Studie 2000: Journalisten Online [Media Studie 2000: Journalists Online]. Hamburg: Newsaktuel.

Manning, P. (2001). News and news sources: A critical introduction. London: Sage.

Middleberg, D. and Ross, S. S. (2001). Survey of media in the wired world 2000: Seventh Annual National Survey. New York: Middleberg Euro RSCG.

Nguyen, A. (2008). Facing the "fabulous monster": The traditional media's fear-driven innovation culture in the development of online news. Journalism Studies, 9, 91-104.

Nie, N. H. and Erbring, L. (2000). Internet and society: A preliminary rReport. Stantford: SIQSS.

Paulussen, S. (2004).Journalistiek@Internet.be: Een Studie naar de Mogelijkheden en Gevolgen van het Internet voor de Journalistieke Nieuwsgaring en Nieuwsproductie [Journalism@Internet.be: A study of the opportunities and implications of the Internet for journalistic news gathering and news production]. Unpublished Ph.D. dissertation. Ghent: University of Ghent, Department of Communication Sciences.

Pavlik, J. V. (2001). Journalism and new media. New York: Columbia University Press.

Pleijter, A., Hermans, L. and Tebbe, F. (2005). Nieuwsgaren op het Web: Internetgebruik in de Nederlandse journalistiek [News gathering on the web: Internet Use by Dutch Journalists]. Tijdschrift voor Communicatiewetenschap 33, 14-31.

Quinn, S. (1999). Internet availability and adoption at Australian daily newspapers, 1997-1999. Communication Research Forum Papers, 2, 319-330.

Rhee, K. Y. and Kim, W. (2004). The adoption and use of the Internet in South Korea. Journal of Computer mediated Communication, 9(4). http://jcmc.indiana.edu/vol9/ issue $4 /$ rhee.html.

Ruggiero, T. E. (2004). Paradigm repair and changing journalistic perceptions of the Internet as an objective news source. Convergence, 10, 92-106.

Singer, J. (2003). Who are these guys? The online challenge to the notion of journalistic professionalism. Journalism, 4, 139-163.

Trumbo, G., Sprecker, K., Dumlao, R., Yun, G. and Duke, S. (2001). Use of e-mail and the web by science writers. Science Communication, 22, 347-378.

Weaver, D. H., Beam, R. A., Brownlee, B. J., Voakes, P. S. and Wilhoit, G. C. (2007). The American journalist in the $21^{\text {st }}$ century. London: Lawrence Erlbaum. 
Internet adoption in the newsroom

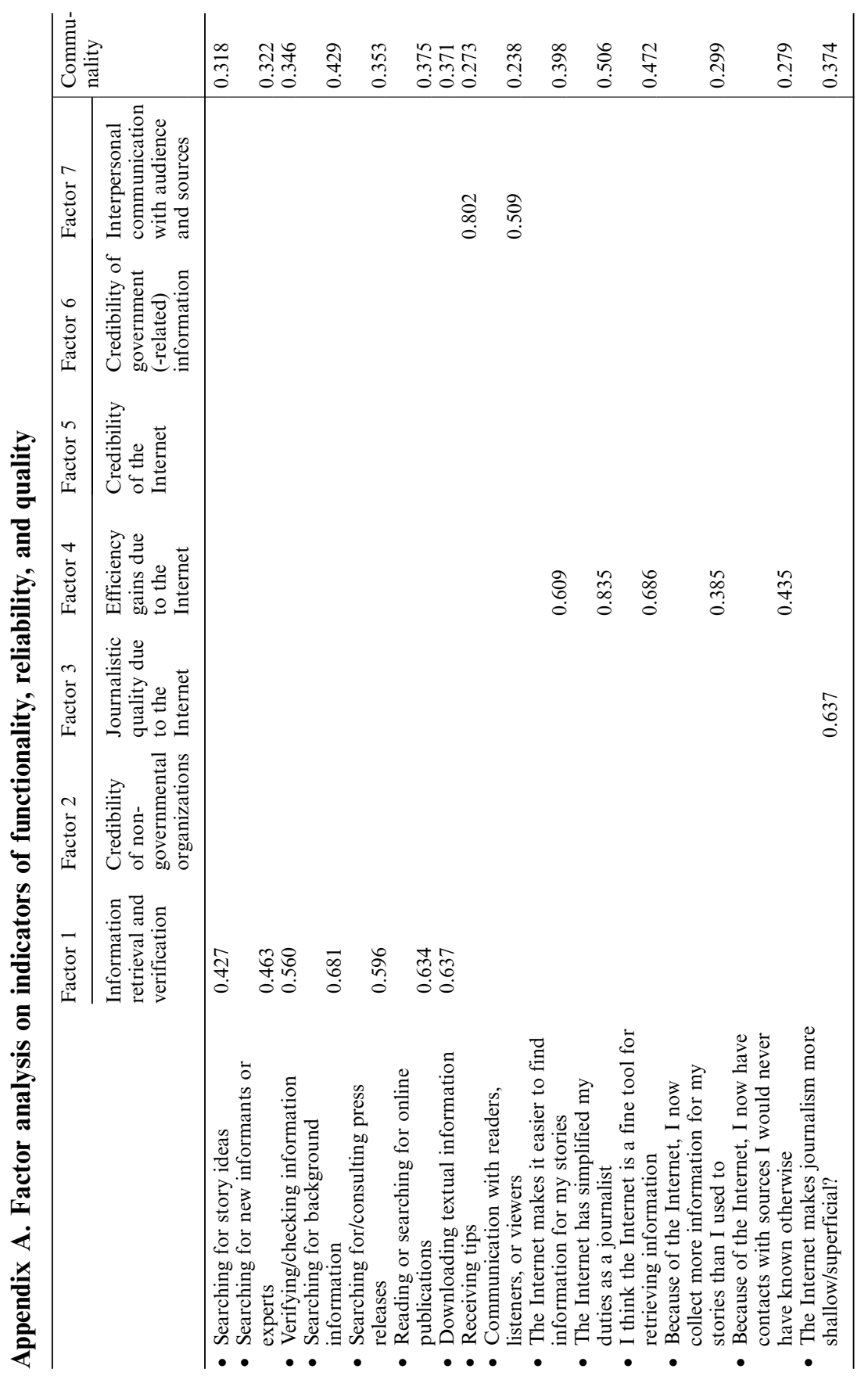




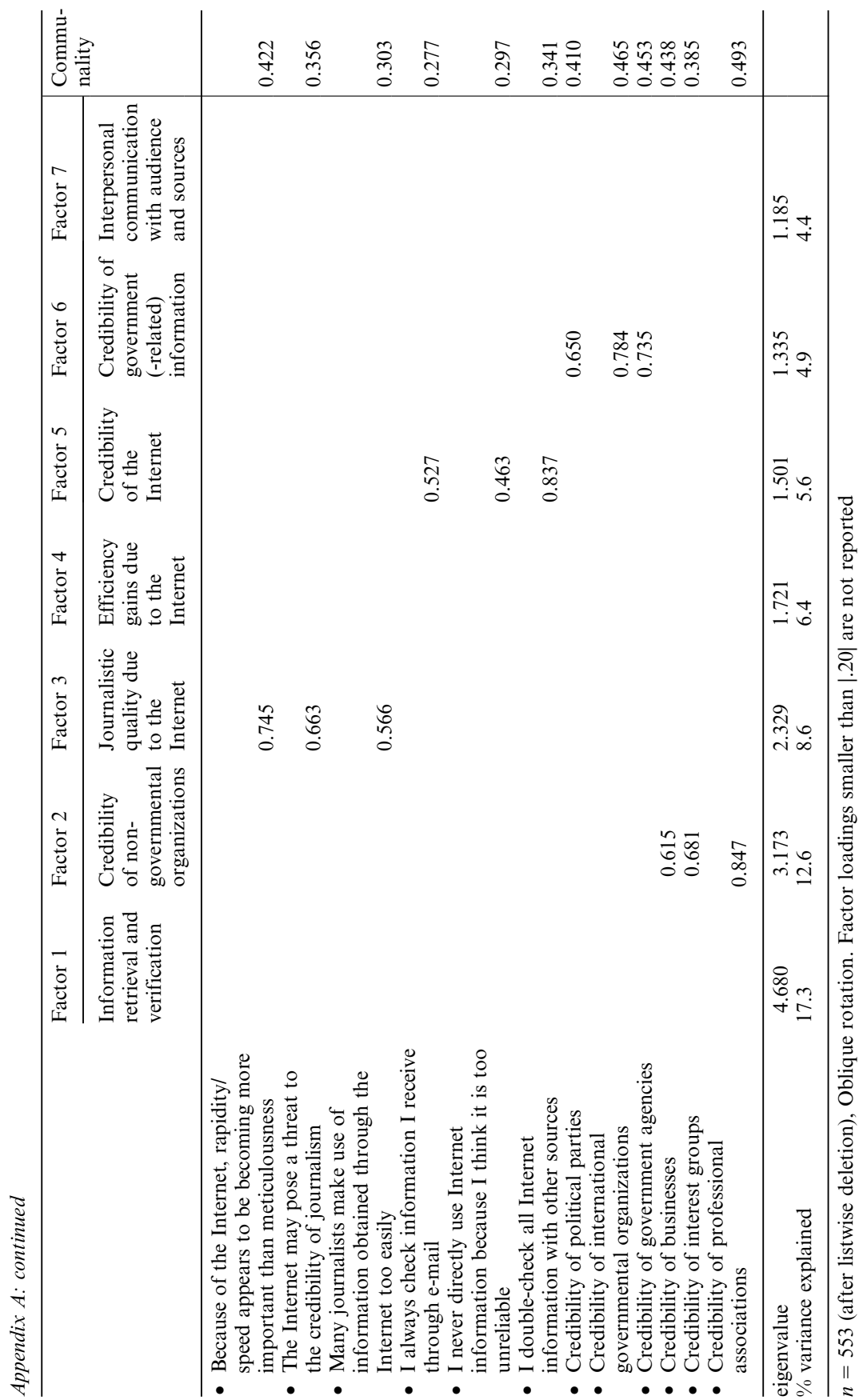


Appendix B. Factor correlation matrix

\begin{tabular}{lrrrrrrr}
\hline Factor & \multicolumn{1}{c}{1} & \multicolumn{1}{c}{2} & 3 & 4 & 5 & 6 & \multicolumn{1}{l}{7} \\
\hline 1 & 1.000 & & & & & & \\
2 & .065 & 1.000 & & & & & \\
3 & -.063 & .091 & 1.000 & & & & \\
4 & .481 & -.038 & -.147 & 1.000 & & & \\
5 & .033 & .133 & .236 & -.060 & 1.000 & & \\
6 & -.104 & .358 & .107 & -.089 & .158 & 1.000 & \\
7 & .343 & -.014 & -.041 & .102 & .086 & -.016 & 1.000 \\
\hline
\end{tabular}

\section{Appendix C. Descriptive statistics of variables}

\begin{tabular}{|c|c|c|c|c|}
\hline & \multicolumn{2}{|c|}{$\begin{array}{l}\text { analysis 1: } \\
\text { Time spent on } \\
\text { Internet use }\end{array}$} & \multicolumn{2}{|c|}{$\begin{array}{l}\text { analysis } 2 \text { : } \\
\text { Diversity of } \\
\text { Internet use }\end{array}$} \\
\hline & Mean & $S D$ & Mean & $S D$ \\
\hline $\begin{array}{l}\text { Internet use } \\
\text { Time spent on the Internet } \\
\text { Diversity of Internet use }\end{array}$ & $\begin{array}{c}1.847 \\
-\end{array}$ & $\begin{array}{c}1.536 \\
-\end{array}$ & $3 . \overline{7} 15$ & $\overline{1 .} 121$ \\
\hline $\begin{array}{l}\text { Demographics } \\
\text { Age }\end{array}$ & 39.393 & 9.315 & 39.409 & 9.312 \\
\hline $\begin{array}{l}\text { Education } \\
\text { University and higher } \\
\text { Higher professional training } \\
\text { Other }\end{array}$ & $\begin{array}{l}0.397 \\
0.449 \\
0.154\end{array}$ & $\begin{array}{l}0.490 \\
0.498 \\
0.361\end{array}$ & $\begin{array}{l}0.395 \\
0.450 \\
0.155\end{array}$ & $\begin{array}{l}0.489 \\
0.498 \\
0.362\end{array}$ \\
\hline $\begin{array}{l}\text { Socialization } \\
\text { Professional socialization } \\
\text { Vocational training } \\
\text { Years of work experience }\end{array}$ & $\begin{array}{l}0.428 \\
3.356\end{array}$ & $\begin{array}{l}0.495 \\
0.831\end{array}$ & $\begin{array}{l}0.430 \\
3.355\end{array}$ & $\begin{array}{l}0.496 \\
0.832\end{array}$ \\
\hline $\begin{array}{l}\text { Internet experience } \\
\text { Courses in Internet use for journalists } \\
\text { Experience using the Internet and e-mail }\end{array}$ & $\begin{array}{l}0.796 \\
6.196\end{array}$ & $\begin{array}{l}0.404 \\
0.904\end{array}$ & $\begin{array}{l}0.795 \\
6.198\end{array}$ & $\begin{array}{l}0.404 \\
0.903\end{array}$ \\
\hline $\begin{array}{l}\text { Position } \\
\text { Managers } \\
\text { Editors } \\
\text { Reporters }\end{array}$ & $\begin{array}{l}0.237 \\
0.204 \\
0.558\end{array}$ & $\begin{array}{l}0.426 \\
0.404 \\
0.497\end{array}$ & $\begin{array}{l}0.238 \\
0.203 \\
0.558\end{array}$ & $\begin{array}{l}0.427 \\
0.403 \\
0.497\end{array}$ \\
\hline $\begin{array}{l}\text { Perceived functionality } \\
\text { Efficiency } \\
\text { Information retrieval and verification } \\
\text { Interpersonal communication with } \\
\text { Audience and sources }\end{array}$ & $\begin{array}{r}11.545 \\
16.039 \\
5.053\end{array}$ & $\begin{array}{l}2.528 \\
5.545 \\
2.172\end{array}$ & $\begin{array}{r}11.550 \\
16.033 \\
5.041\end{array}$ & $\begin{array}{l}2.525 \\
5.546\end{array}$ \\
\hline $\begin{array}{l}\text { Credibility } \\
\text { Internet related trust/credibility } \\
\text { Web info public organizations } \\
\text { Web info private organizations }\end{array}$ & $\begin{array}{l}5.607 \\
8.689 \\
7.158\end{array}$ & $\begin{array}{l}1.837 \\
1.843 \\
2.013\end{array}$ & $\begin{array}{l}5.601 \\
8.688 \\
7.157\end{array}$ & $\begin{array}{l}1.840 \\
1.842 \\
2.009\end{array}$ \\
\hline $\begin{array}{l}\text { Quality } \\
\text { Quality improvement due to the Internet }\end{array}$ & 11.315 & 2.305 & 11.324 & 2.306 \\
\hline$n$ & 514 & & 516 & \\
\hline
\end{tabular}

